\title{
The Dark Corona Character in Seedcoats of Common Bean Cosegregates with the Pink Flower Allele $v^{\text {lae }}$
}

\author{
Mark J. Bassett ${ }^{1}$ \\ Horticultural Sciences Department, IFAS, University of Florida Gainesville, FL 32611 \\ Additional index words. Phaseolus vulgaris, inheritance, genetic linkage
}

\begin{abstract}
Crosses were made with two common bean (Phaseolus vulgaris L.) parents that have pink flowers ( ${ }^{\text {lae }} /-$ ) and mineral-brown seedcoats with dark corona, viz., $v^{\text {lae }} \mathrm{BC}_{3}$ 5-593 (derived from Lamprecht V0491) and $\mathrm{F}_{3} v^{\text {lae }}$ dark corona (derived from Lamprecht M0048). The third parent $v \mathrm{BC}_{2} 5-593$ had white flowers $(\mathrm{v} / \mathrm{v})$ and mineral-brown seedcoats without dark corona (derived from Lamprecht M0056). The $\mathrm{F}_{2}$ progenies of the crosses $v \mathrm{BC}_{2} 5-593 \times v^{\text {lae }} \mathrm{BC}_{3} 5-593$ and $\mathrm{F}_{3} \mathrm{v}^{\text {he }}$ dark corona $\mathrm{x} v \mathrm{BC}_{2} 5-593$ segregated for only two phenotypic classes: either pink flowers and seeds with dark corona or white flowers and seeds without dark corona. Thus, it was demonstrated that the dark corona character (Cor) is either tightly linked to $v^{\text {lae }}\left(<4\right.$ map units) or is a pleiotropic effect of $v^{\text {lae }}$. Pleiotropy is more probable, but tight linkage cannot be ruled out. A linkage of 15 map units between $C$ or and $R$ (currently, $R$ is known to be tightly linked with $C$ ) reported by Lamprecht was not found by subsequent authors, and the linkage map of common bean should be revised accordingly, i.e., no linkage exists between $V(C o r)$ and $C$.
\end{abstract}

In 1985 a program was initiated at the Univ. of Florida to develop genetic stocks with selected marker genes of common bean (Phaseolus vulgaris) in a common genetic background by backcrossing to a recurrent parent. The recurrent parent was a Florida dry bean breeding line, 5-593, that had been developed before 1985. One of the recessive marker characters that was backcrossed into 5-593 was the pink (laelia) flower trait controlled by the $\mathrm{v}^{\text {lac }}$ allele, where the dominant allele $V$ produces bishops violet (purple) flowers and the fully recessive allele v produces pure white flowers (Lamprecht, 1935; Prakken, 1970). The genetic stock carrying the pink flower allele $\mathrm{v}^{\text {ha }}$ was discovered to have a dark (black) corona around the hilum scar of the seeds, which had a mineral-brown color over the remainder of the seedcoat. The dark corona character was reported by Lamprecht (1934) to be controlled by the Cor locus. This paper describes the results of an investigation to test the hypothesis that the $\mathrm{v}^{\text {lac }}$ allele has an unreported pleiotropic effect on seedcoat color pattern, viz., production of a dark corona.

\section{Materials and Methods}

Florida dry bean breeding line 5-593 has determinate habit, purple flowers, and shiny, pure black seedcoats. The seedcoat genotype of 5-593 is TP [C r] D J G B VRk (Bassett, 1994; Prakken, 1970, 1972).

Following the usual recurrent backcross procedure for developing the genetic stocks referred to above, there was strong selection in the $\mathrm{F}_{2}$ generation of each successive backcross for the phenotype of the recurrent parent. The goal was to create a genetic stock that fully recovered the appearance of 5-593 except for the selected marker trait, i.e., there was strong selection against all other marker traits. When the allele $\mathrm{v}$ was substituted into the genetic background of 5-593, giving $P C D J G B v$, it had two pleiotropic effects, viz., changing purple flowers to pure white and changing pure black seedcoats to mineral brown (Prakken, 1970). The source of the v allele was Lamprecht Line M0056 (now PI527830),

Received for publication 9 Sept. 1994. Accepted for publication 14 Dec. 1994 Florida Agricultural Experiment Station Journal Series no. R-03942. The cost of publishing this paper was defrayed in part by the payment of page charges. Under postal regulations, this paper therefore must be hereby marked advertisement solely to indicate this fact.

'Professor. which is known to carry v (Bassett et al., 1990). The resulting stock was designated $\mathrm{v} \mathrm{BC}_{2} 5-593$, indicating two backcrosses to 5-593 with strong selection for the recurrent parent phenotype. The genetic stock $\mathrm{v}^{\text {he }} \mathrm{BC}_{3} 5-593$ was created in a similar manner, using Lamprecht Line V0491 (now PI 527745) as the source of the $\mathrm{v}^{\text {ac }}$ allele. When the $\mathrm{v}^{\text {lac }}$ allele was substituted into the genetic background of 5-593, giving $P C D J G B v^{\text {lae }}$, it had two wellestablished pleiotropic effects, viz., changing purple flowers to pink and changing pure black seedcoat color to mineral brown (Prakken, 1970). The resulting stock was designated $\mathrm{v}^{\text {lac }} \mathrm{BC}_{3}$ 5593, indicating three backcrosses to 5-593 with strong selection for the recurrent parent phenotype. However, $\mathrm{v}^{\text {he }} \mathrm{BC}_{3} 5-593$ had an additional trait not reported in previous literature, viz., a dark (black) corona. The corona phenotypes of $\mathrm{v}^{\text {lac }} \mathrm{BC}_{3} 5-593$ (dark corona) and $\mathrm{v} \mathrm{BC}_{2} 5-593$ (no dark corona) are illustrated in a drawing of the seedcoat patterns on the ventral side of the seeds (Fig. 1). The corona phenotype of $\mathrm{v} \mathrm{BC}_{2} 5-593$ was slightly darker brown than the surrounding mineral-brown seedcoat and was described as having no dark corona (Fig. 1). For additional illustration and discussion of the corona character a good current reference was provided by Leakey (1988).

An additional source of pink flowers and the $\mathrm{v}^{\text {he }}$ allele was used in the investigation, viz., Lamprecht Line M0048 (now PI527829). The letter M signifies multigaris in Lamprecht's terminology, i.e., a line that is derived from the interspecific cross $P$. vulgaris $\mathrm{x} P$. coccineus (formerly multiflorus). Line M0048 has dark seal brown seedcoat color and determinate habit. The dark seal brown color is hypothesized to be the expression of the genotype $P[c R] J G B v^{\text {lac }}$ (M.J. Bassett, unpublished data). The cross M0048 x 5-593 was used to substitute the $[\mathrm{Cr}]$ allele of 5-593 for the $[c \mathrm{R}]$ allele of M0048. Thus, an $\mathrm{F}_{3}$ progeny was obtained that was true breeding for pink flowers and mineral-brown seedcoats with dark corona $(P$ $[C r] J G B v^{\text {lac }}$ ). The line is designated $\mathrm{F}_{3} \mathrm{v}^{\text {lac }}$ dark corona.

Two crosses were made to test the hypothesis that the dark corona character is not controlled by a gene Cor that is independent of $V$, but is a pleiotropic effect of $\mathrm{v}^{\text {lac }}$. The first was $\mathrm{v} \mathrm{BC}_{2} 5-593 \mathrm{x}$ $v^{\text {ha }} \mathrm{BC}_{3} 5-593$, and the "second was $\mathrm{F}_{3} v^{\text {lae }}$ dark corona (seven $\mathrm{F}_{3}$ plants used) $\mathrm{x} v \mathrm{BC}_{2} 5-593$. The $\mathrm{F}_{2}$ plants from the first cross were grown in the field in Spring 1993 and the $\mathrm{F}_{2}$ from the second cross were grown in the field in Spring 1992. Data were taken on the flower and seedcoat color of $F_{1}$ and $F_{2}$ progeny. A single seed was harvested from each plant, keeping the seeds from the two flower 
color classes separate. The seeds were later examined for any indication of segregation for phenotypic classes.

I wrote letters to the curators of several common bean germplasm collections in Europe requesting seed of the two parental lines used by Lamprecht (1934) in the experiments leading to the discovery of Cor, viz., 'de la Chine' (Lamprecht Line 29) and 'Pariser Gelbe' (Lamprecht Line 23). Neither of the parental lines used by Lamprecht (1934) are extant in the U. S. Department of Agriculture plant introduction collection (at Pullman, Wash.) of Lamprecht's experimental materials, PI 527711 through PI 527878 (168 accessions). I was unsuccessful in obtaining seed of 'de la Chine', but I obtained 'Pariser Gelbe' (BGRC \#25351) from the Institut für Pflanzenbau der Bundesforschungsanstalt für Landwirtschaft (FAL), Bundesallee 50, D-38116 Braunschweig, Germany. The seedcoat and corona colors of 'Pariser Gelbe' (\#25351) are identical to the description of Lamprecht (1934), and the seed shape is also the same as his illustration. Seed of 'Pariser Gelbe' (\#25351) was grown in the greenhouse at Gainesville and data were taken on the flower color.

\section{Results and Discussion}

The F, plants from the cross $v \mathrm{BC}_{2} 5-593 \mathrm{x} \mathrm{v}^{\text {lae }} \mathrm{BC}_{3} 5-593$ had pink flowers $\left(v^{\text {lae }} / v\right)$ and mineral-brown seeds with dark corona (data not shown). The $\mathrm{F}_{2}$ segregated for only two phenotypic classes rather than the four classes that would be expected if flower color and dark corona segregated independently (Table 1). Plants with pink flower color always had dark (black) corona, and plants with white flowers always had no dark corona. Thus, there must be either tight linkage between the genes controlling the two characters or pleiotropic effects originating from the $\mathrm{v}^{\text {aa }}$ allele.

There was full dominance for the dark corona trait, whereas Lamprecht (1934) reported partial dominance for dark corona. However, it should be noted that the parental materials of Lamprecht had seedcoat genotypes that were different from the parents in Table 1. For example, Lamprecht Line 23, 'Pariser Gelbe,' had genotype $P C j g b v$ with corona, and Line 29, 'de la Chine,' had genotype $P C j g b v$ without corona. It is probable that 'Pariser Gelbe' carried V Vae , but Lamprecht (1934) did not give information on the flower color and probably omitted the superscript lae as an irrelevant distraction. This view is supported by the observation that 'Pariser Gelbe' (\#2535 1) had pink flowers, which is characteristic of plants with $\mathrm{v}^{\text {lae }}$.

The dark corona in $\mathrm{v}^{\text {lae }} \mathrm{BC}_{3} 5-593$ was black, whereas the corona in 'Pariser Gelbe' was a light purple color. It is my hypothesis that the action of the recessive alleles at $G$ and $B$ greatly reduced the quantity of anthocyannin pigment present (M.J. Bassett, unpublished data; Prakken, 1970). Therefore, the reduction in pigment produced by the heterozygote Cor/cor (really v ${ }^{\text {lac }} / \mathrm{v}$ ) gave a much paler purple corona (Lamprecht, 1934). The genotype cor/ cor (really v/v) had no corona (Lamprecht, 1934). The parental lines derived from 5-593 had dominant alleles at $\mathrm{G}$ and $B$ and, therefore, had a much higher concentration of anthocyanin (Table 1). Thus, the heterozygote $\mathrm{v}^{\text {lae }} / \mathrm{v}$ did not produce a discernible reduction in pigment, but it is probable that a reduction actually took place that is proportional to the one observed by Lamprecht (1934). It is my hypothesis that the absolute concentration of pigment must be reduced to some critical threshold level for the loss to be discernible to the naked eye. Clearly, the partial dominance of $\operatorname{Cor}\left(v^{\text {lae }}\right)$ for corona expression depends on the background genotype for visual evaluation of its expression.

The $\mathrm{F}_{1}$ plants from the cross $\mathrm{F}_{3} \mathrm{v}^{\text {lae }}$ dark coronaxvBC25-593 had pink flowers and mineral-brown seed with dark corona (data not shown). In the $\mathrm{F}_{2}$ progeny, only two phenotypic classes were observed, viz., plants with pink flowers and seeds with dark corona on mineral brown or plants with white flowers and seeds with no darl corona on mineral brown (Table 1). As with the previous cross, there was no independent segregation of flower color and corona color. One must conclude that either the genes are linked or the two characters are pleiotropic effects of a single locus, $V$. Considering the data from both crosses (Table 1), the possible linkage would be less than four map units, as estimated by adding a single (hypothetical) crossover event to the observed data and using the maximum likelihood equations of Allard (1956). One way to symbolically represent such tight linkage is to use the bracket convention, where two or more tightly linked genes are written with their gene symbols enclosed in brackets (Bassett, 1991). For the materials used in the above experiments, the
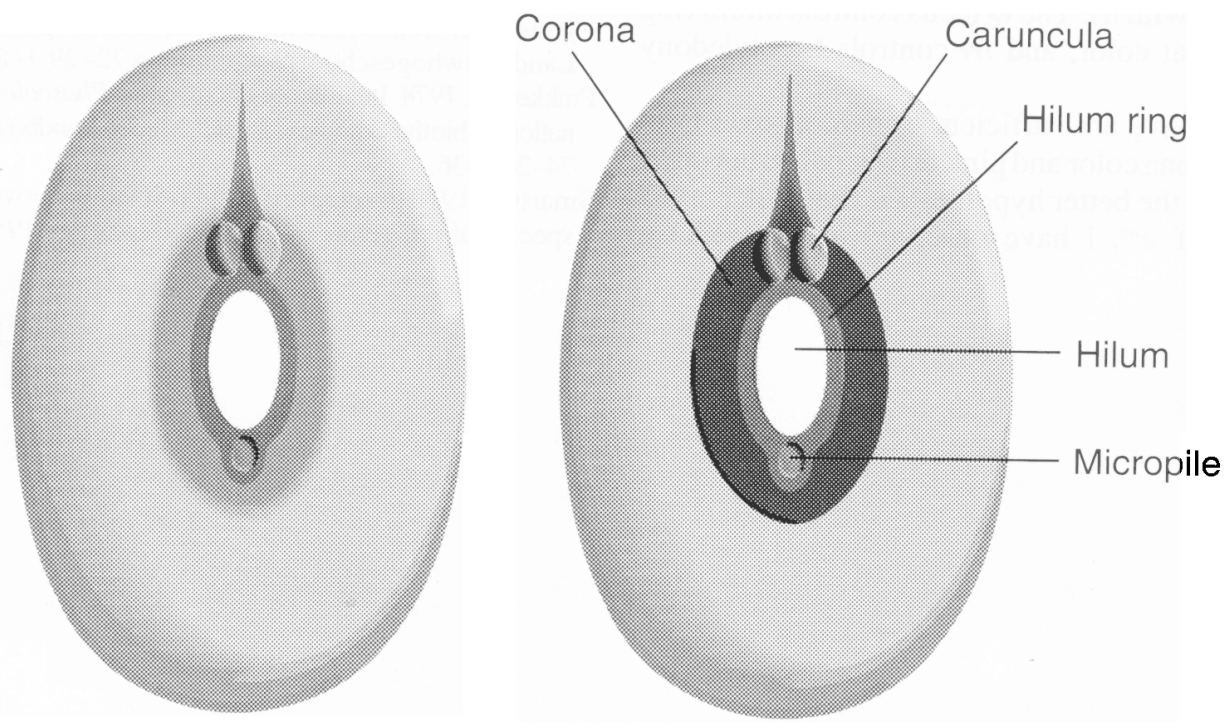

Fig. 1. The seed on the left ( $\left.\mathrm{v} \mathrm{BC}_{2} 5-593\right)$ has no dark corona (light shading indicates a slightly darker brown than the surrounding mineral brown), whereas the seed on the right has dark (black) corona $\left(\mathrm{v}^{\text {lac }} \mathrm{BC}_{3} 5-593\right)$. 
Table 1. Segregation for flower and seed coat color in the $\mathrm{F}_{2}$ from the crosses $\mathrm{v} \mathrm{BC}_{2} 5-593 \mathrm{x} \mathrm{v}^{\text {lae }} \mathrm{BC}_{3} 5-593$, and $\mathrm{F}_{3} v^{\text {lae }}$ dark corona $\mathrm{x} v \mathrm{BC}_{2}$ $5-593$.

\begin{tabular}{lcccc}
\hline \hline & $\begin{array}{c}\text { Pink flowers, } \\
\text { mineral-brown seeds } \\
\text { with dark corona }^{\mathrm{z}}\end{array}$ & $\begin{array}{c}\text { White flowers, } \\
\text { mineral-brown seeds } \\
\text { with no dark corona }\end{array}$ & & \\
Cross & $\chi^{2}$ & $P$ \\
no. & $\left(v^{\text {lae }} /-\right)$ & $(v / v)$ & $3: 1$ & value \\
\hline 1 & 269 & 107 & 2.397 & 0.12 \\
2 & 1247 & 650 & 86.84 & $<0.001$
\end{tabular}

${ }^{\bar{x}}$ The dark corona is black in those genotypes because of dominant $B$. In other genetic backgrounds, $v^{\text {lac }}$ produces various shades of purple in the corona, e.g., with recessive $b$ or $g b$.

'The corona is slightly darker brown than the surrounding mineral brown of the remainder of the seedcoat.

symbols would be [ $v^{\text {lae }} \mathrm{Cor}$ ] for plants with pink flowers and dark corona and [v cor] for plants with white flowers and no corona (Table 1).

The segregation for pink and white flowers in the $\mathrm{F}_{2}$ from the cross $\mathrm{F}_{3} v v^{\text {aae }}$ dark corona $\mathrm{x} v \mathrm{BC}_{2} 5-593$ was highly disturbed in relation to the expected $3: 1$ ratio for pink to white, respectively (Table 1). That result is not surprising, considering that the $\mathrm{F}_{3} \mathrm{v}^{\text {lae }}$ dark corona parent was derived from M0048. The initial cross M0048 x 5-593 also had a highly disturbed 3:1 $\mathrm{F}_{2}$ segregation at the $\boldsymbol{V}$ locus for purple to pink flowers, respectively (data not shown). Disturbed segregation ratios in the progenies from interspecific crosses involving $P$. vulgaris and $P$. coccineus are common and have been frequently reported (as reviewed by Smartt, 1970).

Lamprecht (1961) reported a linkage of 15 map units between Cor and $R$ and incorporated that linkage into his linkage group I. The current view is that $R$ is tightly linked in the complex $C$ locus (Bassett, 1991; Prakken, 1974). If Cor is tightly linked to $v^{\text {lae }}$ as demonstrated by the data (Table 1 ), then the linkage of Lamprecht (1961) translates into a linkage of 15 map units between $V$ and $C$. No such linkage was found in the extensive work by Nakayama (1960, 1964, 1965, 1968) and Prakken (1972) with materials segregating jointly at $V$ and $C$. Linkage group I should be revised accordingly, viz., splitting linkage group I into two separate linkages: $D$ with $V$ and $C$ with tri. The $D$ locus controls hilum ring color, $C$ controls seedcoat color, and tri controls tricotyledony (Bassett, 1991).

The data presented above are sufficient to demonstrate tight linkage between dark corona color and pink flower color, but other observations suggest that the better hypothesis is that dark corona is a pleiotropic effect of $v^{\text {lae }}$. I have observed many seedcoat genotypes in the course of my career and have never observed either of the putative crossover phenotypes, e.g. ( $v$ Cor) with pure white flowers and mineral-brown seeds with dark corona due to the genotype $T P C J G B v$, or ( $v^{\text {lae }}$ cor) with pink flowers and mineralbrown seedcoats with no dark corona due to the genotye TP $P J G$ $B v^{\text {lae }}$. Until such recombinant have been found and verified, the more probable hypothesis is pleiotropy.

\section{Literature Cited}

Allard, R.W. 1956. Formulas and tables to facilitate the calculation of recombinational values in heredity. Hilgardia 24:235-278.

Bassett, M.J. 1991. A revised linkage map of common bean. HortScience 26:834-836.

Bassett, M.J. 1994. The genotype for seed coat color of breeding line 5593. Annu. Rpt. Bean Improv. Coop. 37:244-245.

Bassett, M.J., L.B. Xue, and C. Hannah. 1990. Flower colors in common bean produced by interactions of the $S a l$ and $V$ loci and a gametophyte factor $G a$ linked to Sal. J. Amer. Soc. Hort. Sci. 115:1029-1033.

Lamprecht, H. 1934. Zur Genetik von Phaseolus vulgaris. VII. Zwei weitere Gene für Sameneigenschaften, Cor und Fast. Hereditas 19: 163-176.

Lamprecht, H. 1935. Zur Genetik von Phaseolus vulgaris. XII. Über die Vererbung der Blüten- und Stammfarbe. Hereditas 21:129-166.

Lamprecht, H. 1961. Weitere Koppelungsstudien an Phaseolus vulgaris mit einer Übersicht über die Koppelungsgruppen. Agr. Hort. Genet. 19:319-332.

Leakey, C.L.A. 1988. Genotypic and phenotypic markers in common bean. p. 245-327. In: P. Gepts (ed.). Genetic resources of Phaseolus beans. Kluwer Academic Press, Boston.

Nakayama, R. 1960. Genetical studies on kidney beans (Phaseolus vulgaris). V. On the inheritance of seed coat color 1. Bul. Fat. Agr. Hirosaki Univ. 6:21-36.

Nakayama, R. 1964. Genetical studies on kidney beans (Phaseolus vulgaris). VII. A modifier of flower color and its relation to $c^{u}$ gene. Bul. Fat. Agr. Hirosaki Univ. 10: 1-13.

Nakayama, R. 1965. Genetical studies on kidney beans (Phaseolus vulgaris). VIII. A new allele at the $C$ locus. Bul. Fat. Agr. Hirosaki Univ. 11:55-58.

Nakayarna, R. 1968. Genetical studies on kidney beans (Phaseolus vulgaris). IX. Inheritance of a type of marbling on seed coat in a variety Contender. Bul. Fat. Agr. Hirosaki Univ. 14:9-15.

Prakken, R. 1970. Inheritance of colour in Phaseolus vulgaris L. II. Critical review. Meded. Landbouwhogeschool Wageningen 70-23: 1-38.

Prakken, R. 1972. Inheritance of colours in Phaseolus vulgaris L. III. On genes for red seedcoat colour and a general synthesis. Meded. Landbouwhogeschool Wageningen 72-29: 1-82.

Prakken, R. 1974. Inheritance of colours in Phaseolus vulgaris L. IV. Recombination within the 'complexlocusC'. Meded. Landbouwhogeschcol Wageningen 74-24:1-36.

Smartt, J. 1970. Interspecific hybridization between cultivated American species of the genus Phaseolus. Euphytica 19:480-489. 